Sains Malaysiana 49(5)(2020): 971-978

http://dx.doi.org/10.17576/jsm-2020-4905-1

\title{
Pengimunan Protein Rekombinan SAG2 Eimeria tenella Melindungi Ayam terhadap Kesan Penyakit Koksidiosis
}

(Immunisation of Eimeria tenella SAG2 Recombinant Protein Protects Chickens against the Effects of Coccidiosis)

\author{
Sue-Kim Ho, Mandeepal Singh Atar Singh, Sheila NATHan \& KiEW-Lian WaN*
}

\begin{abstract}
ABSTRAK
Pengawalan penyakit koksidiosis ayam yang disebabkan oleh jangkitan parasit Eimeria melibatkan penggunaan vaksin hidup. Namun, kaedah ini mempunyai batasan disebabkan kos pengeluarannya yang tinggi secara relatif dan hanya memberikan perlindungan yang terhad disebabkan oleh sifat Eimeria yang khusus-hos. Justeru, vaksin rekombinan diperkenalkan sebagai strategi alternatif. Antigen permukaan-2 (SAG2) Eimeria tenella telah dikenal pasti berupaya merangsang gerak balas imun ayam berikutan jangkitan. Oleh itu, dalam kajian ini, protein rekombinan SAG2 terlarut telah dihasil dan digunakan dalam pengimunan ayam. Hasil ELISA menggunakan sampel ayam terimun menunjukkan bahawa program pengimunan berjaya merangsang penghasilan antibodi-khusus SAG2 pada ayam terimun. Antibodi IgG, IgM dan IgA khusus-SAG2 pada serum ayam berjaya dikesan selepas suntikan perangsang yang pertama, manakala IgA rembesan khusus-SAG2 dikesan pada sampel kandungan mukosa ayam yang telah melengkapkan keseluruhan program pengimunan. Ayam seterusnya telah diberikan jangkitan cabaran oosista tersporulasi E. tenella. Hasil menunjukkn bahawa ayam terimun menghasilkan bilangan oosista yang lebih rendah berbanding dengan ayam tidak terimun $(p<0.05)$ dan ini mencadangkan keupayaan protein rekombinan SAG2 untuk melindungi ayam terhadap kesan jangkitan E. tenella. Secara keseluruhannya, hasil kajian ini menunjukkan kesesuaian protein rekombinan SAG2 E. tenella sebagai calon vaksin rekombinan bagi penyakit koksidiosis.
\end{abstract}

Kata kunci: Antigen permukaan-2; ELISA; vaksin rekombinan

\section{ABSTRACT}

The control of avian coccidiosis caused by Eimeria parasites involves the use of live vaccines. However, this method has its limits due to relatively high production cost and restricted protection because of the host-specific characteristic of Eimeria. Hence, recombinant vaccines were introduced as an alternative strategy. The surface antigen-2 (SAG2) of Eimeria tenella has been shown to be able to stimulate the chicken immune response upon infection. Therefore, in this study, purified soluble recombinant proteins of SAG2 were produced and used to immunise chickens. The results obtained by ELISA through the use of samples from immunised chickens indicated that the immunisation programme was successful in inducing the production of SAG2-specific antibodies in immunised chickens. SAG2-specific IgG, IgM, and IgA antibodies were detected in the sera of immunised chickens after the first boosting injection, while SAG2specific secretory IgA was detected in mucosal samples of the chickens that completed the immunisation program. The chickens were subsequently given a challenge dose of sporulated oocysts of E. tenella. Results indicated that the immunised chickens produced a significantly lower number of oocysts compared to their non-immunised counterparts $(p<0.05)$, suggesting the ability of the recombinant protein SAG2 to protect chickens against the effects of E. tenella infection. Overall, the results of this study indicate the suitability of the E. tenella SAG2 recombinant protein as a recombinant vaccine candidate for coccidiosis.

Keywords: ELISA; recombinant vaccines; surface antigen-2

\section{PENGENALAN}

Penyakit koksidiosis ayam disebabkan oleh parasit Eimeria, termasuk E. tenella, E. necatrix, E. acervulina, E. brunetti, E. praecox, E. maxima dan E. mitis. Penyakit ini mengakibatkan kerugian yang besar terhadap sektor penternakan ayam, dengan mencecah sehingga US\$3 bilion setiap tahun (Dalloul \& Lillehoj 2006; Williams 1999). Kawalan koksidiosis yang digunakan merangkumi kaedah kemoterapi dan pemvaksinan. Kaedah kemoterapi melibatkan penggunaan dadah antikoksidia yang ditambah pada makanan ayam dan mempunyai batasan disebabkan wujudnya strain yang rintang terhadap dadah antikoksidia yang digunakan (Djemai et al. 2016; Witcombe \& Smith 2014). Kaedah pemvaksinan menggunakan vaksin hidup pula didapati hanya memberikan perlindungan yang terbatas memandangkan Eimeria adalah bersifat 
khusus-hos (Smith et al. 2002). Penghasilan vaksin hidup juga melibatkan kos yang tinggi secara relatifnya (Blake \& Tomley 2014). Maka, vaksin rekombinan telah diperkenalkan sebagai strategi alternatif untuk menangani koksidiosis (Blake et al. 2017). Penghasilan antigen secara rekombinan adalah menjimatkan dan dapat dihasilkan dalam skala yang besar dengan masa yang pendek.

Antigen permukaan telah dilaporkan berupaya untuk memberikan perlindungan terhadap kesan penyakit yang disebabkan oleh jangkitan parasit dengan memodulasikan proses utama pada parasit semasa berlakunya pencerobohan hos (Gilson et al. 2006). Antigen permukaan (SAG) E. tenella meliputi permukaan parasit dan diekspres semasa parasit berada pada tahap invasif (Reid et al. 2014; Tabarés et al. 2004). Salah satu daripada SAG E. tenella, iaitu SAG2 didapati berupaya untuk mengaruh penghasilan tahap antibodi yang tinggi pada ayam terjangkit E. tenella (Chow et al. 2011).

Dalam kajian ini, protein rekombinan SAG2 yang terlarut daripada $E$. tenella telah dihasilkan dan ditulenkan. Protein rekombinan SAG2 terlarut yang tertulen seterusnya digunakan untuk pengimunan ayam bagi mengenal pasti sifat imunogenik protein tersebut. Seterusnya, kesan pengimunan protein rekombinan SAG2 $E$. tenella terhadap jangkitan $E$. tenella telah dikenal pasti. Hasil kajian ini adalah penting dan berguna dalam usaha pembangunan vaksin subunit yang berkesan dalam menangani penyakit koksidiosis.

\section{BAHAN DAN KAEDAH}

\section{PENGHASILAN OOSISTA TERSPORULASI}

Propagasi E. tenella strain Houghton (H) telah dilakukan dalam ayam bebas patogen khusus (SPF) untuk memperoleh oosista tersporulasi. Ayam SPF telah diberikan makanan dan minuman ayam yang bebas daripada dadah antikoksidia dan dibekalkan secara ad libitum. Kebenaran menjalankan uji kaji yang melibatkan ayam SPF telah diperoleh daripada Jawatankuasa Etika Haiwan Universiti Kebangsaan Malaysia (UKMAEC) (kod kelulusan FST/2014/WAN/24SEPT./617-SEPT.-2014-AUG.-2016).

\section{PENGEKSPRESAN DAN PENULENAN PROTEIN REKOMBINAN SAG2 Eimeria tenella}

Plasmid pET32b yang mengandungi gen $S A G 2$ telah dihasilkan pada kajian terdahulu (Chow et al. 2011) dan digunakan dalam kajian ini. Plasmid pET32b SAG2 telah diekstrak, ditulen serta ditransformasi ke dalam hos pengekspresan E. coli Rosetta gami (DE3) (Novagen). Hasil transformasi seterusnya dikultur di dalam kaldu LB yang mengandungi karbenisilin $(50 \mu \mathrm{g} /$ $\mathrm{mL})$ dan kloramfenikol $(34 \mu \mathrm{g} / \mathrm{mL})$ pada $37{ }^{\circ} \mathrm{C}$ dengan goncangan $250 \mathrm{rpm}$. Selepas pengeraman semalaman, sebanyak $3 \mathrm{~mL}$ kultur ditambah ke dalam $300 \mathrm{~mL}$ kaldu LB yang mengandungi $50 \mu \mathrm{g} / \mathrm{mL}$ karbenisilin dan $34 \mu \mathrm{g} / \mathrm{mL}$ kloramfenikol. Apabila ketumpatan optik mencapai 0.5-0.6 pada panjang gelombang $600 \mathrm{~nm}$, pengekspresan protein diaruh dengan $0.1 \mathrm{mM}$ isopropil $\beta$-D-1-tiogalaktopiranosida (IPTG) selama 20 jam pada $20{ }^{\circ} \mathrm{C}$ dengan goncangan $200 \mathrm{rpm}$. Pelet terhasil melalui pengemparan kultur bakteria pada $4{ }^{\circ} \mathrm{C}$ dengan kelajuan $5000 \times g$ selama 10 minit. Sebanyak $6 \mathrm{~mL}$ larutan BugBuster $^{\circledR}$ (Novagen, USA) seterusnya ditambah bagi melisiskan sel. Protein rekombinan SAG2 yang terlarut diperoleh daripada bahagian supernatan yang terhasil selepas pengemparan pada $4{ }^{\circ} \mathrm{C}$ dengan kelajuan 18000 $\times g$ selama 20 minit.

Protein rekombinan SAG2 terlarut seterusnya dilakukan penulenan secara natif yang dimulakan dengan penambahan $1.5 \mathrm{~mL}$ resin Ni-NTA pada $20 \mathrm{mg}$ protein rekombinan terlarut, yang ditambah dengan $1 \mathrm{M} \mathrm{NaCl}$, $50 \mathrm{mM} \mathrm{NaH} \mathrm{PO}_{4}$ dan $70 \mathrm{mM}$ imidazol. Penimbal pembasuhan turus yang digunakan merupakan larutan penimbal yang masing-masing ditambah dengan 20 $\mathrm{mM}, 40 \mathrm{mM}, 60 \mathrm{mM}, 80 \mathrm{mM}$ dan $100 \mathrm{mM}$ imidazol. Pengelutan protein dilakukan dengan menggunakan larutan penimbal yang ditambahkan dengan $300 \mathrm{mM}$ imidazol. Semua fraksi yang dikumpul dianalisis menggunakan elektroferosis gel poliakrimida-natrium dodesil sulfida (SDS-PAGE) dan pemblotan western. Fraksi yang mengandungi protein rekombinan SAG tertulen dipekat dan dinyahgaram melalui penukaran penimbal kepada penimbal PBS pH 7.4 menggunakan Amicon ${ }^{\circledR}$ Ultra Centrifugal Filters (Millipore, USA). Kepekatan protein diperoleh menggunakan asai asid bisikoninik.

\section{ANALISIS PROTEIN REKOMBINAN SAG2 Eimeria tenella}

Fraksi protein rekombinan terlarut yang diekstrak dan ditulenkan diasingkan melalui SDS-PAGE (Laemmli 1970). Gel SDS-PAGE yang disediakan terdiri daripada $12 \%$ gel pemisah dan $5 \%$ gel pemampat. Selepas elektroforesis dilakukan, gel pemisah SDS-PAGE diwarnakan selama 15 minit dalam larutan pewarna yang mengandungi Coomasie blue.

Kehadiran protein rekombinan SAG2 dalam fraksi protein seterusnya dikenal pasti melalui pemblotan western (Towbin at al. 1979). Protein terasing dipindah ke membran polivinilidin dwiflorida (PVDF) yang telah dibasahkan terlebih dahulu dengan 100\% metanol menggunakan sistem Sel Mini Trans-Blot (Bio-Rad, USA). Selepas kehadiran protein pada membran PVDF ditentukan melalui pewarnaan pewarna Ponceau $S$ dan dinyahwarna dengan air suling, membran PVDF dieram dalam 5\% susu skim selama 1 jam pada suhu bilik dengan goncangan bagi mengelakkan pengikatan tidak khusus. Pembasuhan membran seterusnya dilakukan dengan menggunakan larutan PBS, diikuti dengan pengeraman dalam antibodi poliklon IgG mencit antihistidina (Santa-Cruz Biotechnology, 1:500) dengan goncangan selama 1 jam pada suhu bilik. Membran 
seterusnya dibasuh dengan larutan PBST (PBS dengan $0.1 \%$ Tween-20) dan dieram dalam antibodi monoklon arnab anti-IgG mencit berkonjugat HRP (Santa-Cruz Biotechnology, 1:250) selama 1 jam pada suhu bilik dengan goncangan. Pembasuhan membran dilakukan sekali lagi dan larutan daripada kit WesternBright ${ }^{\mathrm{TM}}$ Sirius dicampurkan serta disebarkan ke atas membran. Pengesanan isyarat dilakukan dengan menggunakan mesin pengimejan Omega Lum $^{\mathrm{TM}} G$ (Aplegen, USA).

\section{PENYEDIAAN SERUM DAN BAHAN MUKOSA AYAM} TERIMUN

Protokol imunisasi ayam diubah suai daripada Lai et al. (2011). Sebanyak tiga suntikan telah diberikan kepada semua ayam uji kaji, dengan $100 \mu \mathrm{g}$ protein rekombinan SAG2 tertulen disuntik secara subkutan. Suntikan primer dilakukan semasa ayam berumur dua minggu dan dilakukan bersama adjuvan TiterMax Gold (SigmaAldrich, USA). Suntikan perangsang yang pertama diberikan seminggu selepas suntikan primer, manakala suntikan perangsang yang kedua diberikan dua minggu selepas suntikan perangsang yang pertama. Kedua-dua suntikan perangsang diberikan bersama dengan adjuvan Freund tidak lengkap (Sigma-Aldrich, USA). Kumpulan kawalan terdiri daripada ayam SPF yang tidak diberikan sebarang suntikan.

Bagi penyediaan serum ayam, ayam dibahagikan kepada kumpulan ayam terimunisasi $(n=6)$ dan kumpulan ayam tidak terimunisasi $(n=6)$. Semua sampel darah ayam diperoleh melalui pendarahan kepak dan dikumpul seminggu selepas setiap suntikan. Darah ayam seterusnya dieram pada $37^{\circ} \mathrm{C}$ selama sejam dan pada 4 ${ }^{\circ} \mathrm{C}$ untuk semalaman. Serum ayam seterusnya diperoleh selepas pengemparan dilakukan pada $10000 \times g$ selama 10 minit. Sebelum suntikan pertama dilakukan, darah ayam uji kaji yang dicatat sebagai sampel pra-imun turut dikumpul untuk dijadikan kawalan dan digunakan untuk pengiraan nilai pemutus.

Bagi penyediaan bahan mukosa ayam, sebanyak empat ekor ayam SPF terimun dikorbankan seminggu selepas suntikan perangsang sekunder. Sebelum imunisasi dimulakan, sebanyak tiga ekor ayam telah dikorbankan untuk dijadikan sebagai sampel kawalan dan digunakan untuk pengiraan nilai pemutus. Sejurus selepas ayam dikorbankan, sekum ayam diperoleh dan kandungan mukosa daripada sampel sekum telah diekstrak melalui kaedah yang diubah suai daripada Wagner et al. (2015).

\section{IMUNOASAI JERAPAN TERANGKAI ENZIM (ELISA)}

Sebanyak $1 \mu \mathrm{g}$ protein rekombinan SAG2 yang tertulen dijerap pada telaga piring mikrotiter 96 (Sigma-Aldrich, USA), menggunakan sebanyak $100 \mu \mathrm{L}$ penimbal penjerap $\left(0.1 \mathrm{M} \mathrm{NaHCO}_{3}\right)$ dan dieram untuk semalaman. Pada keesokan harinya, telaga piring dilakukan pemblokan dengan menggunakan sebanyak $150 \mu \mathrm{L} 5 \%$ susu skim dan dieram selama sejam pada suhu $37{ }^{\circ} \mathrm{C}$. Telaga seterusnya dibasuh dengan menggunakan penimbal TBS dan sebanyak $100 \mu \mathrm{L}$ serum ayam yang telah dilakukan pencairan 1:25 dalam 5\% susu skim ditambah. Sampel kandungan mukosa ayam pula tidak dicairkan dan ditambah terus pada telaga. Pengeraman dilakukan lagi selama sejam pada suhu $37{ }^{\circ} \mathrm{C}$. Telaga dibasuh sebanyak 10 kali menggunakan penimbal TBST (Penimbal TBS dengan $0.05 \%$ Tween 20 ), dan sebanyak $100 \mu \mathrm{L}$ antibodi poliklon kambing anti-IgG ayam berkonjugat dengan amonium peroksidase (AP) (Bethyl Laboratories Inc., USA; 1:500) ditambah ke dalam telaga dan dieram selama sejam pada $37{ }^{\circ} \mathrm{C}$. Telaga dibasuh sekali lagi, diikuti dengan penambahan $50 \mu \mathrm{L}$ substrat 1-step PNPP (Thermo-Scientific, USA). Pengeraman dilakukan selama 30 minit dan bacaan penyerapan pada panjang gelombang $450 \mathrm{~nm}$ diambil menggunakan mesin pembaca piring mikrotiter Sunrise (Tecan, Switzerland). Sampel serum turut dilakukan penyaringan ELISA menggunakan antibodi poliklon kambing anti-IgA ayam berkonjugat AP (Bethyl Laboratories Inc., USA; 1:500) dan antibodi poliklon kambing anti-IgM ayam berkonjugat AP (Bethyl Laboratories Inc., USA; 1:500). Bagi sampel kandungan mukosa ayam, penyaringan ELISA melibatkan penggunaan antibodi poliklon kambing antiIgA ayam berkonjugat AP (Bethyl Laboratories Inc., USA; 1:500) sahaja.

\section{PERLINDUNGAN AYAM TERHADAP KESAN CABARAN Eimeria tenella}

Seminggu selepas suntikan imunisasi terakhir, cabaran dilakukan. Ayam SPF disuap paksa dengan 250 oosista tersporulasi E. tenella. Oosista tersporulasi E. tenella telah diperoleh melalui propagasi menggunakan ayam SPF. Proses ini melibatkan suapan paksa oosista tersporulasi terhadap ayam SPF. Ayam SPF terjangkit seterusnya dibela untuk seminggu sebelum disembelih. Oosista E. tenella yang diperoleh daripada sekum ayam kemudiannya dilakukan proses sporulasi dan penulenan. Dos suapan paksa seterusnya dihitung menggunakan slaid pembilang Fuchs-Rosenthal. Sepanjang uji kaji, ayam SPF diberikan makanan dan minuman mencukupi, yang bebas daripada dadah antikoksidia. Selepas itu, bagi mengenal pasti kesan perlindungan ayam terhadap jangkitan E. tenella, tinja ayam dikumpul daripada hari ke-lima hingga hari ke-11 pasca-cabaran dan kandungan oosista dihitung menggunakan kebuk pembilang McMaster.

\section{ANALISIS STATISTIK}

Dalam analisis gerak balas imun ayam, nilai pemutus ditentukan berdasarkan purata nilai penyerapan ELISA menggunakan serum pra-imun yang ditambah tiga kali sisihan piawainya (Chow et al. 2011). Sampel dianggap positif sekiranya mempunyai purata nilai penyerapan ELISA sama atau melebihi nilai pemutus yang dihitung. Persamaan untuk mengira nilai pemutus adalah seperti berikut:

Nilai pemutus $=$ Purata untuk sampel pra-imun $+(3$ 
$\times$ sisihan piawai bagi sampel pra-imun)

Bagi analisis perlindungan ayam terimun selepas cabaran, analisis statistik dilakukan dengan menggunakan ujian $\mathrm{t}$ pelajar tak berpasangan. Nilai p yang kurang daripada $0.05(\mathrm{p}<0.05)$ dianggap sebagai signifikan.

\section{HASIL}

Analisis SDS-PAGE pada protein rekombinan SAG2 terekspres menunjukkan bahawa protein rekombinan SAG2 yang terlarut telah berjaya diekspres dan mempunyai saiz kira-kira $43 \mathrm{kDa}$ (Rajah 1(A)). Analisis pemblotan western menggunakan antibodi anti-His pula berjaya mengesahkan penghasilan protein rekombinan SAG2 terlarut (Rajah 1(B)). Penulenan protein menggunakan kromatografi afiniti berganding logam nikel pula berjaya menghasilkan protein rekombinan SAG2 terlarut yang tertulen, seperti yang ditunjukkan pada Rajah 1, yang digunakan dalam pemvaksinan ayam dan ELISA.

Sampel serum dan bahan mukosa ayam yang diperoleh sepanjang pemvaksinan telah digunakan untuk penentuan kehadiran antibodi khusus-SAG2 pada ayam terimun. Berdasarkan hasil imunoasai jerapan terangkai enzim, program pengimunan berjaya menghasilkan antibodi khusus-SAG2 pada ayam terimun (Rajah 2). Bagi antibodi IgG khusus-SAG2 pada serum ayam, nilai penyerapan adalah melebihi nilai pemutus $\left(\mathrm{OD}_{405}=2.04\right)$ selepas suntikan perangsang yang pertama dan terus berada pada tahap yang sama walaupun suntikan perangsang yang kedua diberikan (Rajah 2(A)). Seperti antibodi IgG, antibodi IgM khusus-SAG2 pada serum ayam turut dikesan dan mempunyai nilai penyerapan yang melebihi nilai pemutus $\left(\mathrm{OD}_{405}=1.19\right)$ seawal selepas suntikan perangsang yang pertama dan terus berada pada tahap yang sama sepanjang program pengimunan (Rajah 2(B)).

Bagi antibodi IgA khusus-SAG2 pada serum ayam, nilai bacaan penyerapan ELISA yang diperoleh adalah amat rendah (Rajah 2C). Walaupun suntikan perangsang yang pertama mampu memberikan nilai penyerapan yang melebihi nilai pemutus $\left(\mathrm{OD}_{405}=0.65\right)$, tahap antibodi menunjukkan profil yang menurun meskipun suntikan perangsang yang kedua diberikan. Oleh itu, sampel bahan mukosa digunakan bagi menilai kehadiran antibodi IgA rembesan khusus-SAG2 selepas keseluruhan program pengimunan. Hasil menunjukkan bahawa antibodi IgA rembesan khusus-SAG2 dapat dikesan pada sampel bahan mukosa dengan nilai penyerapan yang melebihi nilai pemutus $\left(\mathrm{OD}_{405}=0.80\right)$ selepas program pengimunan (Rajah 2D).

Ayam uji kaji yang telah diberikan ketiga-tiga suntikan protein rekombinan SAG2 telah dicabar dengan 250 oosista tersporulasi E. tenella melalui suapan paksa. Selepas itu, tahap perlindungan ditentukan melalui pengiraan jumlah bilangan oosista $E$. tenella yang dihitung dalam tinja ayam yang terkumpul. Seperti yang ditunjukkan pada Rajah 3, bilangan oosista yang dihasilkan dalam ayam terimun protein rekombinan SAG2 tertulen $\left((3.65 \pm 0.30) \times 10^{7}\right.$ oosista $)$ berkurangan secara signifikan $(\mathrm{p}<0.05)$ berbanding dengan bilangan oosista yang dihasilkan dalam ayam tidak terimun $\left((5.74 \pm 0.52) \times 10^{7}\right.$ oosista). Ini menunjukkan bahawa imunisasi protein rekombinan SAG2 bukan sahaja berupaya untuk mengaktifkan perembesan antibodi khusus-SAG2, malahan mampu untuk mengurangkan jumlah oosista yang terhasil akibat jangkitan E. tenella.

PERBINCANGAN

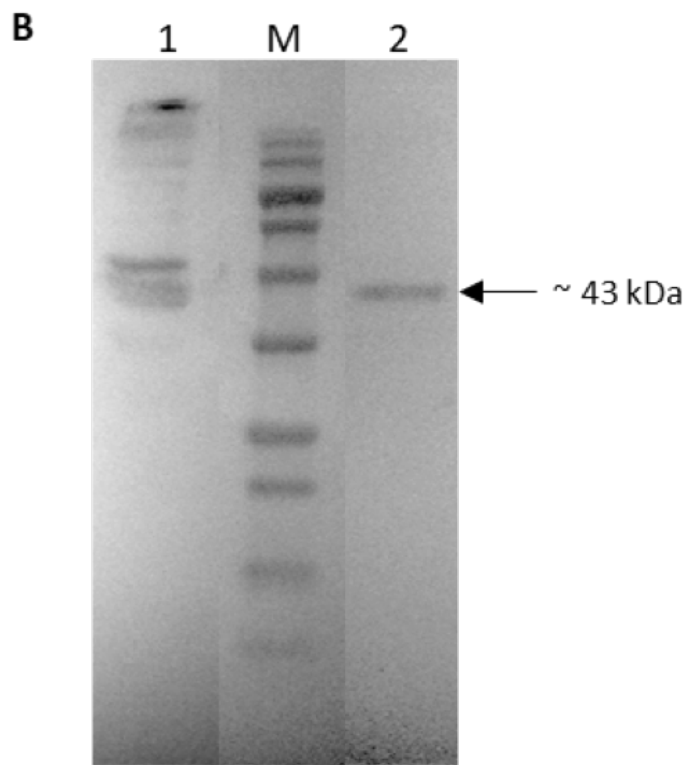

RAJAH 1. Analisis hasil pengekspresan dan penulenan protein rekombinan SAG2 E. tenella

Profil (A) SDS-PAGE dan (B) pemblotan western protein rekombinan SAG2 terekspres dan tertulen. Lajur 1: protein rekombinan SAG2 terekspres; Lajur M: penanda protein Prestained (New England Biolabs, USA); Lajur 2: protein rekombinan SAG2 terekspres yang tertulen 
A

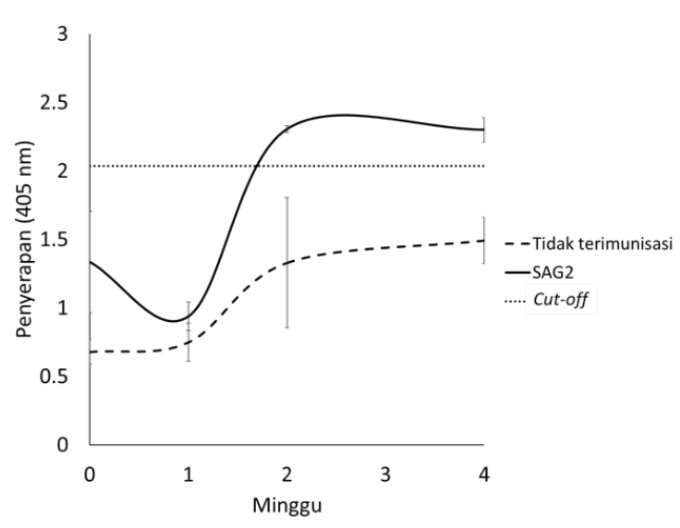

C

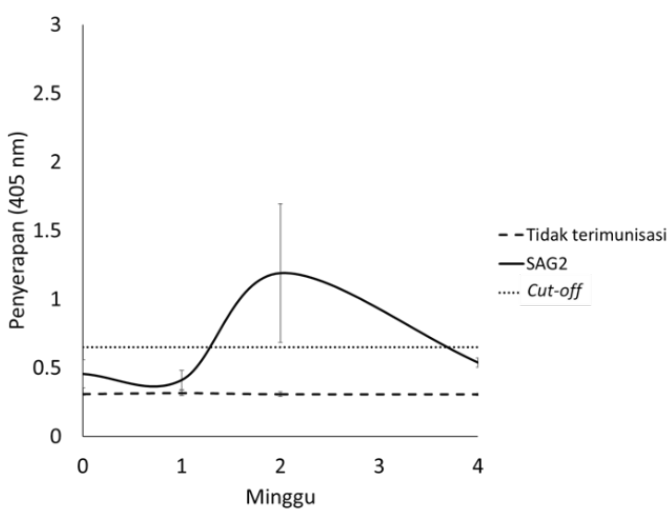

B

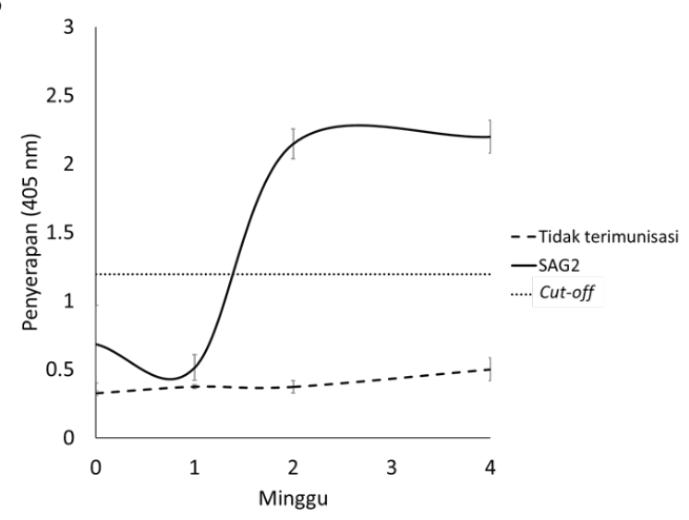

D

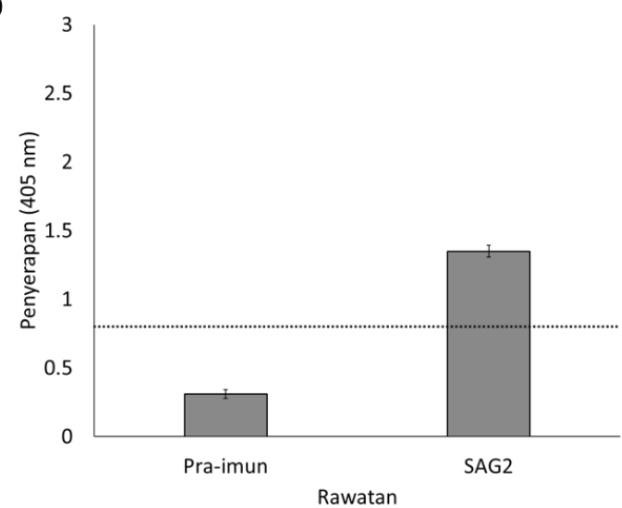

RAJAH 2. Profil purata nilai bacaan penyerapan ELISA untuk antibodi khusus-SAG2

(A) Profil IgG khusus-SAG2 pada sampel serum ayam terimun; (B) Profil IgM khusus-SAG2 pada sampel serum ayam terimun; (C) Profil IgA khusus-SAG2 pada sampel serum ayam terimun; (D) Profil IgA rembesan khusus-SAG2 pada sampel bahan mukosa ayam terimun. Garisan bertitik mewakili nilai cut-off yang dihitung. Semua nilai penyerapan dicatat sebagai Purata \pm SEM

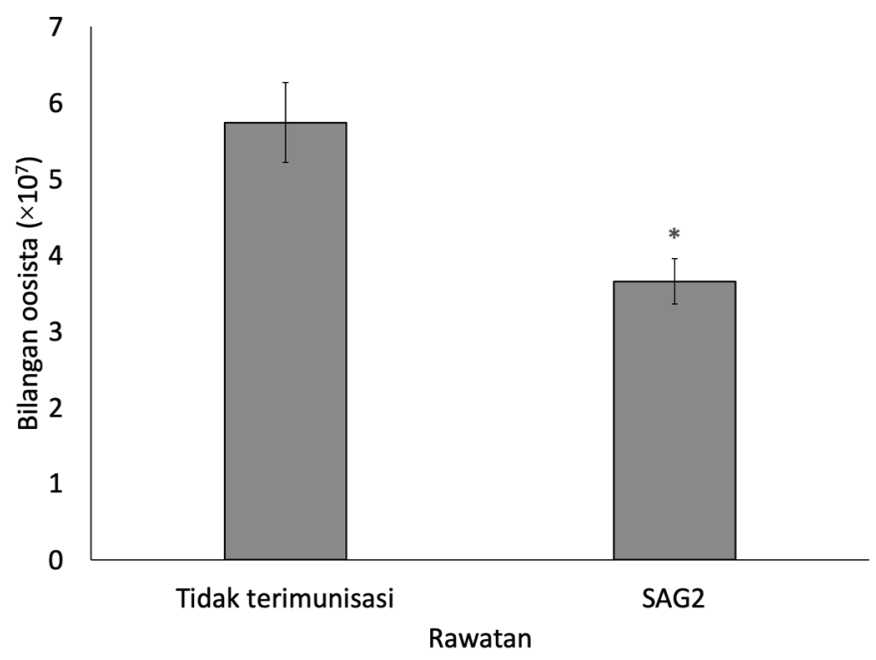

RAJAH 3. Bilangan oosista dalam tinja ayam selepas ayam dicabar menggunakan oosista tersporulasi E. tenella

Tinja ayam telah dikumpul pada hari kelima hingga ke-11 pasca-cabaran. Bilangan oosista yang dihitung dicatatkan sebagai Purata \pm SEM. Simbol asterisk $\left(^{*}\right)$ menunjukkan perbezaan yang signifikan berbanding dengan ayam tidak terimun berdasarkan ujian t pelajar tak berpasangan $(\mathrm{p}<0.05)$

Kawalan parasit Eimeria secara berkesan adalah penting dalam memastikan pengkomersialan penghasilan ternakan ayam yang berjaya. Sehingga kini, penggunaan kaedah kemoterapi profilaktik dan pemvaksinan memainkan peranan yang penting dalam pengawalan penyakit koksidiosis (Blake \& Tomley 2014). Namun, cabaran dihadapi apabila wujudnya strain Eimeria yang rintang terhadap dadah ionofor yang digunakan, manakala penghasilan vaksin hidup memerlukan ayam 
yang mengakibatkan penghasilannya adalah kurang cekap daripada segi kos dan skala. Justeru, penggunaan vaksin rekombinan telah diperkenalkan.

Vaksin rekombinan terdiri daripada protein rekombinan antigen parasit yang terekspres. Antara contoh protein rekombinan antigen $E$. tenella yang didapati berupaya melindungi ayam daripada kesan koksidiosis dan berpotensi sebagai vaksin rekombinan adalah CHP559 (Zhai et al. 2016), faktor pemanjangan$1 \alpha(\mathrm{EF}-1 \alpha)$ (Lin et al. 2017), protein pemetaan imun1 (IMP-1) (Kundu et al. 2017; Yin et al. 2015, 2014, 2013), serta protein rekombinan bagi protein mikronim 3 (MIC3) (Lai et al. 2011). Memandangkan SAG merangkumi sebahagian besar antigen pada permukaan parasit dan didapati berperanan dalam merangsang gerak balas imun ayam (Tabarés et al. 2004), kajian ini dijalankan untuk menilai kesesuaian protein rekombinan SAG2 E. tenella sebagai calon vaksin rekombinan penyakit koksidiosis.

Pengekspresan protein rekombinan SAG2 telah dilakukan menggunakan Escherichia coli Rosetta gami (DE3). Sistem pengekspresan E. coli mempunyai kos penghasilan yang rendah dengan aliran kerja yang mudah. Selain itu, pertumbuhan E. coli adalah cepat, mempunyai genetik yang telah dicirikan dan mempunyai pilihan vektor dan strain hos yang banyak (Baneyx 1999; Hua et al. 2004, Verma et al. 1998). Strain E. coli Rosetta gami (DE3) yang digunakan pula mampu membekalkan tRNA terhadap kodon jarang yang wujud pada jujukan SAG2 dan menyediakan keadaan sitoplasma yang lebih sesuai untuk pembentukan ikatan disulfida pada protein SAG2 yang dihasilkan (Bessette et al. 1999; Derman et al. 1993). Protein rekombinan SAG2 terlarut seterusnya dilakukan penulenan dalam keadaan natif melalui kromatografi afiniti berganding logam nikel. Cara penulenan ini bukan sahaja mudah dikendalikan, tetapi mempunyai kecekapan serta kapasiti yang tinggi, dan tidak sensitif terhadap penglipatan protein yang tidak betul. Malahan ia dipilih kerana protein rekombinan SAG2 terekspres mempunyai jujukan polihistidina pada kedua-dua hujung-N dan hujung-C protein. Jujukan ini mempunyai keafinan yang tinggi terhadap ion nikel yang berkelat dengan manik agarosa yang digunakan dalam penulenan. Pengelutan seterusnya dilakukan menggunakan imidazol. Kepekatan imidazol yang semakin meningkat mengelutkan protein yang mempunyai jujukan histidina seperti protein rekombinan SAG2 yang digunakan dalam kajian ini.

Protein rekombinan SAG2 terlarut yang tertulen digunakan untuk pemvaksinan ayam. Sebanyak tiga suntikan diberikan kepada ayam uji kaji, yang terdiri daripada satu suntikan primer bersama dengan adjuvan TiterMax Gold dan dua kali suntikan sekunder bersama dengan adjuvan tidak lengkap Freund. Adjuvan TiterMax Gold yang digunakan semasa suntikan primer telah diformulasikan dengan skualena bagi menghasilkan emulsi air-dalam-minyak yang stabil. Emulsi yang dihasilkan juga berciri kurang melekit, membenarkan suntikan dilakukan melalui jarum yang halus. Adjuvan lengkap Freund yang biasanya digunakan bersama dengan suntikan primer pula didapati cenderung terhadap gerak balas imun jenis Th1 pada ayam (Shibaki \& Katz 2001; Stills 2005). Manakala penggunaan TiterMax Gold sebagai adjuvan untuk suntikan primer memberikan gerak balas jenis Th1/Th2 yang lebih sekata (Stephenson et al. 2014). Adjuvan TiterMax Gold turut mampu menghasilkan titer antibodi yang tinggi semasa digunakan. Bagi adjuvan lengkap Freund, adjuvan ini mengandungi Mycobacterium tuberculosis yang berfungsi untuk menarik sel makrofaj ke bahagian suntikan agar dapat membantu dalam gerak balas imun yang terhasil.

Seterusnya, sampel serum dan bahan mukosa telah diperoleh pada titik masa yang tertentu daripada ayam yang telah melengkapi keseluruhan program imunisasi. Sampel serum telah digunakan untuk pengenalpastian tahap antibodi IgG khusus-SAG2, antibodi IgM khususSAG2, dan antibodi IgA khusus-SAG2; manakala sampel bahan mukosa digunakan untuk mengenal pasti tahap antibodi IgA rembesan khusus-SAG2. Ini adalah kerana IgA rembesan pada usus ayam mempunyai peranan yang penting dalam menghasilkan gerak balas imun perlindungan terhadap kesan jangkitan E. tenella (Davis at al. 1978). Antibodi IgG dan IgM berupaya menyebabkan aglutinasi apabila berinteraksi dengan antigen pada permukaan mikrob atau parasit dan adalah penting dalam pengaktifan sistem pelengkap (Janeway et al. 2001). Jangkitan Eimeria mampu mengaktifkan gerak balas imun yang memulakan penghasilan antibodi yang dikesan pada sistem peredaran darah, rembesan mukosa usus, ataupun pada rembesan hempedu (Yun et al. 2000). Dalam kajian ini, imunisasi protein rekombinan SAG2 berjaya menghasilkan gerak balas imun yang kuat pada ayam dan bersifat imunogenik.

Antibodi yang dihasilkan memberi kesan perlindungan terhadap jangkitan yang berlaku dan merupakan modulator bagi gerak balas imun di perantara sel (Mockett \& Rose 1986). Kajian lepas oleh Belli et al. (2009), Constantinoui et al. (2011) dan Wallach (2010) telah melaporkan bahawa imunoglobulin mampu memberikan kesan perlindungan terhadap jangkitan Eimeria. Oleh itu, ayam terimun protein rekombinan SAG2 telah dicabar dengan menggunakan oosista tersporulasi E. tenella bagi menilai kesan perlindungan SAG2 terhadap ayam melalui pengiraan bilangan oosista pada tinja ayam selepas cabaran.

Dos 250 oosista tersporulasi E. tenella dipilih sebagai dos suapan paksa untuk mengelak berlakunya situasi kesan berkerumun pada kajian yang dijalankan. Kesan berkerumun wujud sebagai salah satu faktor yang akan mempengaruhi bilangan oosista yang terhasil pasca-jangkitan (Brackett \& Bliznick 1952; Williams 1973). Kesan ini terhasil daripada penambahan dos jangkitan oosista tersporulasi yang mampu menghasilkan oosista yang lebih banyak, sehingga mencapai suatu tahap penambahan dos tidak mampu lagi untuk menambahkan bilangan oosista yang terhasil disebabkan jangkitan. Penambahan dos yang keterlaluan pula akan mengakibatkan penurunan dalam bilangan oosista yang terhasil. Selain itu, potensi penghasilan oosista akan 
menurun apabila jangkitan dilakukan pada dos yang tinggi (Williams 2001).

Perlindungan ayam daripada kesan jangkitan Eimeria menggunakan vaksin rekombinan telah ditunjukkan dalam beberapa kajian lepas. Dalam kajian Zhai et al (2016), protein rekombinan CHP559 daripada E. tenella berupaya melindungi ayam daripada kesan jangkitan $E$. tenella strain Shanghai dengan mencatat bilangan oosista pada tinja yang lebih rendah pada ayam terimun apabila dibandingkan dengan ayam kawalan tidak terimunisasi. Lin et al. (2017) telah mengekspres protein EF-1 $\alpha$ E. tenella dan mendapati bahawa ayam terimun mempunyai bilangan oosista pada tinja ayam yang berkurangan bersama dengan tahap antibodi khusus-EF-1 $\alpha$ yang tinggi. Imunisasi protein rekombinan IMP-1 daripada $E$. tenella turut terbukti memberikan perlindungan kepada ayam terhadap koksidiosis, dengan bilangan oosista dalam tinja yang lebih rendah berbanding dengan ayam tidak terimunisasi (Kundu et al. 2017; Yin et al. 2015, 2014, 2013).

Selain itu, Liu et al. (2018) mendapati bahawa ayam terimun dengan SAG E. maxima mempunyai bilangan oosista pada tinja yang lebih rendah, apabila dibandingkan dengan ayam kawalan tidak terimun. Ini menunjukkan SAG E. maxima berupaya untuk melindungi ayam daripada kesan jangkitan Eimeria. Ayam terimun protein rekombinan SAG2 pada kajian ini mencatatkan bilangan oosista pada tinja ayam yang berkurangan secara signifikan berbanding dengan ayam tidak terimunisasi. Ini mencadangkan bahawa protein rekombinan SAG2 mampu memberikan perlindungan terhadap kesan jangkitan E. tenella dan wajar dibangunkan sebagai vaksin rekombinan bagi mengawal penyakit koksidiosis yang disebabkan oleh parasit ini.

\section{KESIMPULAN}

Dalam kajian ini, protein rekombinan SAG2 terlarut yang tertulen telah berjaya dihasilkan. Pengimunan ayam menggunakan protein rekombinan SAG2 berjaya menghasilkan tahap antibodi yang tinggi bagi IgG, IgM dan IgA khusus-SAG2 pada serum ayam terimun serta antibodi IgA rembesan khusus-SAG2 pada bahan mukosa ayam. Cabaran ayam terimun menggunakan oosista tersporulasi $E$. tenella pula berjaya menunjukkan bahawa ayam terimun mempunyai bilangan oosista pada tinja ayam yang kurang daripada ayam tidak terimun secara signifikan. Ini menunjukkan bahawa protein ini berupaya untuk melindungi ayam terhadap kesan jangkitan E. tenella dan boleh dijadikan sebagai calon vaksin rekombinan bagi penyakit koksidiosis.

\section{PENGHARGAAN}

Kajian ini telah dibiaya menggunakan geran penyelidikan Kementerian Sains, Teknologi dan Inovasi (MOSTI) (02-01-02-SF1105). Penghargaan turut ditujukan kepada Kementerian Pengajian Tinggi Malaysia yang telah membiayai yuran pengajian SKH melalui MyBrain15.

\section{RUJUKAN}

Baneyx, F. 1999. Recombinant protein expression in Escherichia coli. Current Opinions in Biotechnology 10: 411-421.

Belli, S.I., Ferguson, D.J., Katrib, M., Slapetova, I., Mai, K., Slapeta, J., Flowers, S.A., Miska, K.B., Tomley, F.M., Shirley, M.W. \& Wallach, M.G. 2009. Conservation of proteins involved in oocyst wall formation in Eimeria maxima, Eimeria tenella and Eimeria acervulina. International Journal for Parasitology 39(10): 1063-1070.

Bessette, P.H., Åslund, F., Beckwith, J. \& Georgiou, G. 1999. Efficient folding of proteins with multiple disulfide bonds in the Escherichia coli cytoplasm. Proceedings of the National Academy of Sciences U.S.A. 96(24): 1370313708.

Blake, D.P. \& Tomley, F.M. 2014. Securing poultry production from the ever-present Eimeria challenge. Trends in Parasitology 30: 12-19.

Blake, D.P., Pastor-Fernández, I., Nolan, M.J. \& Tomley, F.M. 2017. Recombinant anticoccidial vaccines - a cup half full? Infection, Genetics and Evolution 55: 358-365.

Brackett, S. \& Bliznick, A. 1952. The reproductive potential of five species of coccidia of the chicken as demonstrated by oocyst production. The Journal of Parasitology 38(2): 133-139.

Chow, Y.P., Wan, K.L., Blake, D.P., Tomley, F. \& Nathan, S. 2011. Immunogenic Eimeria tenella glycosylphosphatidylinositolanchored surface antigens (SAGs) induce inflammatory responses in avian macrophages. PLoS ONE 6(9): e25233.

Constantinoui, C.C., Molley, J.B., Jorgenson, W.K. \& Coleman, G.T. 2011. Characterisation of the antibody response in birds following infection with wild type and attenuated strains of Eimeria tenella. Veterinary Parasitology 175: 47-51.

Dalloul, R.A. \& Lillehoj, H.S. 2006. Poultry coccidiosis: Recent advancements in control measures and vaccine development. Expert Review of Vaccines 5(1): 143-163.

Davis, P.J., Parry, S.H. \& Porter, P. 1978. The role of secretory IgA in anti-coccidial immunity in the chicken. Immunology 34(5): 879-888.

Derman, A.I., Prinz, W.A., Belin, D. \& Beckwith, J. 1993. Mutations that allow disulfide bond formation in the cytoplasm of Escherichia coli. Science 262(5140): 17441747.

Djemai, S., Mekroud, A. \& Jenkins, M.C. 2016. Evaluation of ionophore sensitivity of Eimeria acervulina and Eimeria maxima isolated from the Algerian to Jijel province poultry farms. Veterinary Parasitology 224: 77-81.

Gilson, P.R., Nebl, T., Vukcevic, D., Moritz, R.L., Sargeant, T., Speed, T.P., Schofield, L. \& Crabb, B.S. 2006. Identification and stoichiometry of glycosylphosphatidylinositolanchored membrane proteins of the human malaria parasite Plasmodium falciparum. Molecular and Cellular Proteomics 5: 1286-1299.

Hua, Q., Yang, C., Oshima, T., Mori, H. \& Shimizu, K. 2004. Analysis of gene expression in Escherichia coli in response to changes of growth-limiting nutrient in chemostat cultures. Application of Environmental Microbiology 70: 2354-2366.

Janeway, C.A., Travers, P., Walport, M. \& Shlomchik, M. 2001. Immunobiology: The Immune System in Health and Disease. Edisi ke-5. New York: Garland Publishing.

Kundu, K., Garg, R., Kumar, S., Mandal, M., Tomley, F.M., Blake, 
D.P. \& Banerjee, P.S. 2017. Humoral and cytokine response elicited during immunisation with recombinant Immune Mapped protein-1 (EtIMP-1) and oocysts of Eimeria tenella. Veterinary Parasitology 244: 44-53.

Laemmli, U.K. 1970. Cleavage of structural proteins during the assembly of the head of bacteriophage T4. Nature 227(5259): 680-685.

Lai, L., Bumstead, J., Liu, Y., Garnett, J., Campanero-Rhodes, M.A., Blake, D.P., Palma, A.S., Chai, W., Ferguson, D.J., Simpson, P. \& Feizi, T. 2011. The role of sialyl glycan recognition in host tissue tropism of the avian parasite Eimeria tenella. PLoS Pathogens 7(10): e1002296.

Lin, R.Q., Lillehoj, H.S., Lee, S.K., Oh, S., Panebra, A. \& Lillehoj, E.P. 2017. Vaccination with Eimeria tenella elongation factor- $1 \alpha$ recombinant protein induces protective immunity against $E$. tenella and E. maxima infections. Veterinary Parasitology 243: 79-84.

Liu, T., Huang, J., Li, Y., Ehsan, M., Wang, S., Zhou, Z., Song, X., Yan, R., Xu, L. \& Li, X. 2018. Molecular characterisation and the protective immunity evaluation of Eimeria maxima surface antigen gene. Parasites \& Vectors 11(1): 325.

Mockett, A.P. \& Rose, M.E. 1986. Immune responses to Eimeria: Quantification of antibody isotypes to Eimeria tenella in chicken serum and bile by means of the ELISA. Parasite Immunology 8(5): 481-489.

Reid, A.J., Blake, D.P., Ansari, H.R., Billington, K., Browne, H.P., Bryant, J., Dunn, M., Hung, S.S., Kawahara, F., MirandaSaavedra, D., Malas, T.B., Mourier, T., Naghra, H., Nair, M., Otto, T.D., Rawlings, N.D., Rivailler, P., Sanchez-Flores, A., Sanders, M., Subramaniam, C., Tay, Y.L., Woo, Y., Wu, X., Barrell, B., Dear, P.H., Doerig, C., Gruber, A., Ivens, A.C., Parkinson, J., Rajandream, M.A., Shirley, M.W., Wan, K.L., Berriman, M., Tomley, F.M. \& Pain, A. 2014. Genomic analysis of the causative agents of coccidiosis in domestic chickens. Genome Research 24: 1676-1685.

Shibaki, A. \& Katz, S.I. 2002. Induction of skewed Th1/Th2 T-cell differentiation via subcutaneous immunization with Freund's adjuvant. Experimental Dermatology 11(2): 126134.

Smith, A.L., Hesketh, P., Archer, A. \& Shirley, M.W. 2002. Antigenic diversity in Eimeria maxima and the influence of host genetics and immunization schedule on crossprotective immunity. Infection and Immunity 70(5): 2472-2479.

Stephenson, R., You, H., McManus, D.P. \& Toth, I. 2014. Schistosome vaccine adjuvants in preclinical and clinical research. Vaccines 2(3): 654-685.

Stills, H.F. Jr. 2005. Adjuvants and antibody production: Dispelling the myths associated with Freund's complete and other adjuvants. ILAR Journal 46(3): 280-293.

Tabarés, E., Ferguson, D., Clark, J., Soon, P.E., Wan, K.L. \& Tomley, F. 2004. Eimeria tenella sporozoites and merozoites differentially express glycosylphosphotidylinositol-anchored variant surface proteins. Molecular \& Biochemical Parasitology 135: 123-132.

Towbin, H., Staehelin, T. \& Gordon, J. 1979. Electrophoretic transfer of proteins from polyacrylamide gels to nitrocellulose sheets: Procedure and some applications. Proceedings of the National Academy of Sciences U.S.A. 76(9): 4350-4354.

Verma, R., Boleti, E. \& George, A.J. 1998. Antibody engineering: Comparison of bacterial, yeast, insect and mammalian expression systems. Journal of Immunological Methods 216: $165-181$.

Wagner, A., Schabussova, I., Ruttkowski, B., Peschke, R., Kur,
J., Kundi, M., Joachim, A. \& Wiedermann, U. 2015. Primeboost vaccination with Toxoplasma lysate antigen, but not with a mixture of recombinant protein antigens, leads to reduction of brain cyst formation in BALB/c mice. PLoS ONE 10(5): e0126334.

Wallach, M. 2010. Role of antibody in immunity and control of chicken coccidiosis. Trends in Parasitology 26(8): 382-387.

Williams, R.B. 1973. Effects of different infection rates on the oocyst production of Eimeria acervulina or Eimeria tenella in the chicken. Parasitology 67(3): 279-288.

Williams, R. 1999. A compartmentalised model for the estimation of the cost of coccidiosis to the world's chicken production industry. International Journal for Parasitology 29: 12091229.

Williams, R.B. 2001. Quantification of the crowding effect during infections with the seven Eimeria species of the domesticated fowl: Its importance for experimental designs and the production of oocyst stocks. International Journal for Parasitology 31(10): 1056-1069.

Witcombe, D.M. \& Smith, N.C. 2014. Strategies for anti-coccidial prophylaxis. Parasitology 141: 1379-1389.

Yin, G., Lin, Q., Qiu, J., Qin, M., Tang, X., Suo, X., Huang, Z. \& Liu, X. 2015. Immunogenicity and protective efficacy of an Eimeria vaccine candidate based on Eimeria tenella immune mapped protein 1 and chicken CD40 ligand. Veterinary Parasitology 210(1-2): 19-24.

Yin, G., Lin, Q., Wei, W., Qin, M., Liu, X., Suo, X. \& Huang, Z. 2014. Protective immunity against Eimeria tenella infection in chickens induced by immunization with a recombinant C-terminal derivative of EtIMP1. Veterinary Immunology and Immunopathology 162(3-4): 117-121.

Yin, G., Qin, M., Liu, X., Suo, J., Tang, X., Tao, G., Han, Q., Suo, X. \& Wu, W. 2013. An Eimeria vaccine candidate based on Eimeria tenella immune mapped protein 1 and the TLR-5 agonist Salmonella typhimurium FliC flagellin. Biochemical and Biophysical Research Communications 440(3): 437-442.

Yun, C.H., Lillehoj, H.S. \& Lillehoj, E.P. 2000. Intestinal immune responses to coccidiosis. Developmental \& Comparative Immunology 24(2-3): 303-324.

Zhai, Q., Huang, B., Dong, H., Zhao, Q., Zhu, S., Liang, S., Li, S., Yang, S. \& Han, H. 2016. Molecular characterization and immune protection of a new conserved hypothetical protein of Eimeria tenella. PLOS ONE 11(6): e0157678.

Sue-Kim Ho, Sheila Nathan \& Kiew-Lian Wan*

Pusat Bioteknologi dan Makanan Berfungsi

Fakulti Sains dan Teknologi

Universiti Kebangsaan Malaysia

43600 UKM Bangi, Selangor Darul Ehsan

Malaysia

Sue-Kim Ho, Mandeepal Singh Atar Singh, Sheila Nathan \& Kiew-Lian Wan*

Pusat Pengajian Biosains dan Bioteknologi

Fakulti Sains dan Teknologi

Universiti Kebangsaan Malaysia

43600 UKM Bangi, Selangor Darul Ehsan

Malaysia

*Pengarang untuk surat-menyurat; email:klwan@ukm.edu.my

Diserahkan: 8 Oktober 2019

Diterima: 9 Januari 2020 